\title{
Frequencies and intensities of defoliation in Aruana Guineagrass swards: accumulation and morphological composition of forage ${ }^{1}$
}

\author{
Guilherme Doneda Zanini², Gabriela Trevisan Santos², André Fischer Sbrissia ${ }^{3}$
}

\footnotetext{
1 Project funded by FAPESC - Fundação de Amparo à Pesquisa e Inovação do Estado de Santa Catarina.

2 Programa de Pós-Graduação em Ciência Animal, UDESC/CAV, Lages, SC.

${ }^{3}$ Departamento de Produção Animal e Alimentos, Universidade do Estado de Santa Catarina (UDESC/CAV). Avenida Luiz de Camões, 2090, 88520-000, Lages, SC.
}

\begin{abstract}
The objective of this study was to assess the accumulation and morphological composition of forage in Aruana Guineagrass (Panicum maximum cv. Aruana) swards subjected to intermittent stocking with sheep. Experimental treatments when grazing was introduced included low (95\%) and high (98\%) incident light interception and low (10 cm)- and high $(15 \mathrm{~cm})$-residue height and were allocated to experimental units (196 $\mathrm{m}^{2}$ fenced areas) in a completely randomized $2 \times 2$ factorial arrangement with three replicates. Treatments were imposed between January and May 2009. More frequent grazing cycles (95\% light interception) resulted in better control of stem elongation, lower proportion of dead plant material and invasive plants, and higher proportions of leaf blades in the grazing strata, compared with less frequent grazing cycles (98\% light interception). Grass managed with 95\% light interception combined with 10 and 15 cm post-grazing height and grass managed at 98\% light interception combined with $15 \mathrm{~cm}$ post-grazing height did not show differences in forage accumulation rate. These results indicate that more frequent $(30 \mathrm{~cm}$ pre-grazing height) and less severe (15 cm post-grazing height) grazing cycles provided animals with high leaf blade mass and low stem mass forage.
\end{abstract}

Key Words: grazing management, light interception, Panicum maximum, post-grazing height

\section{Introduction}

The spatial structure of swards has a significant influence on animal grazing behavior because the height and availability of preferred components have clear effects on instantaneous intake rate and bite mass (Amaral, 2009). Several environmental factors, including temperature, water and nutrients influence how forage accumulates. Thus, the structure of the grass sward is determined by the processes of plant decline and senescence along with defoliation, which depends on grazing management (Chacon \& Stobbs, 1976). This, in turn, influences the responses of plants and animals (Hodgson, 1985; Chapman \& Lemaire, 1993) because it determines the patterns of light interception and access by animals (Laca \& Lemaire, 2000).

Grazing management techniques used to optimize forage production in swards must seek to reach a compromise between the need to retain sufficient leaf area for photosynthesis and the need to remove leaf tissue before senescence (Hodgson \& Da Silva, 2002) to meet established forage production goals (Parsons \& Penning, 1988). Therefore, the net forage accumulation of a species results from the difference between gross weight increase due to new tissue formation and reduction caused by senescence and decomposition of older tissue, or by forage consumption (Bircham \& Hodgson, 1983; Davies et al., 1983). In a study on Mombasa-grass subjected to intermittent stocking strategies, Da Silva et al. (2009) observed that pre- and postgrazing forage masses were lower with 95\% light interception treatments compared with $100 \%$ light interception; however, the proportion of leaves was higher and the proportion of stems and dead plant material was lower in the former treatment. Cano et al. (2004) studied Tanzaniagrass and concluded that the nutritional value of leaf blades was higher compared with the stem + sheath fraction, regardless of forage canopy height and study duration, indicating that grass management should focus on the contribution of leaf forage mass. As a rule, prolonged regrowth periods of species exhibiting early stem elongation make it more difficult to control the forage canopy, and this might limit subsequent leaf blade accumulation and the production of high-quality forage.

Aruana Guineagrass (Panicum maximum Jacques cv. Aruana) was officially introduced in 1995, by Instituto de Zootecnia de Nova Odessa, São Paulo, Brazil; it has been systematically tested and recommended for use in this Brazilian state. However, there are no data available on the production potential and adaptability of this cultivar in the 
southern area of Brazil, nor are there precise indications as to how to manage this plant for maximal production. Thus, the objective of this study was to assess the effects of variation in the frequency and severity of grazing by sheep on the accumulation and morphological composition of forage in Aruana Guineagrass swards in order to understand and facilitate planning and management to ensure appropriate use of this forage plant.

\section{Material and Methods}

This study was carried out between January and May 2009 at the Center for Agro-veterinary Sciences of Universidade do Estado de Santa Catarina (UDESC/CAV). The study site is located at an altitude of $913 \mathrm{~m}$ on approximately $27^{\circ} 47^{\prime}$ Southern latitude and $50^{\circ} 18^{\prime}$ Western longitude in the municipality of Lages, Santa Catarina. The geographical relief of the area is mildly to moderately undulated, and the soil is haplic cambisol (Embrapa, 2006). The chemical characteristics of the soil before the onset of the study were as follows: 5.2 water $\mathrm{pH}, 7.5 \mathrm{mg} / \mathrm{dm}^{3} \mathrm{P}$, $164 \mathrm{mg} / \mathrm{dm}^{3} \mathrm{~K}, 5.1 \mathrm{cmol}_{c} / \mathrm{dm}^{3} \mathrm{Ca}, 3.5 \mathrm{cmol}_{c} / \mathrm{dm}^{3} \mathrm{Mg}$, $6.7 \mathrm{cmol}_{\mathrm{c}} / \mathrm{dm}^{3} \mathrm{H}+\mathrm{Al}$ and $0.3 \mathrm{cmol}_{\mathrm{c}} / \mathrm{dm}^{3} \mathrm{Al}$.

The soil was prepared conventionally using plowing and harrowing in the beginning of September 2008. Seeds were cast by sowing during the second half of October, with $10 \mathrm{~kg} / \mathrm{ha}$ of seeds (cultural value $=32 \%$ ), which were buried to 1 to $2 \mathrm{~cm}$ depth through harrowing followed by a compaction roller. The regional climate is subtropical, with no dry season and with cool summers. The average temperature is from 9.2 to $10.8^{\circ} \mathrm{C}$ in the coldest months and 19.4 to $22.3^{\circ} \mathrm{C}$ in the warmest months (Braga \& Ghellre, 1999). Climate data during this study were collected at the UDESC/ CAV experimental meteorological station, which is located at approximately $250 \mathrm{~m}$ from the study area (Figure 1).

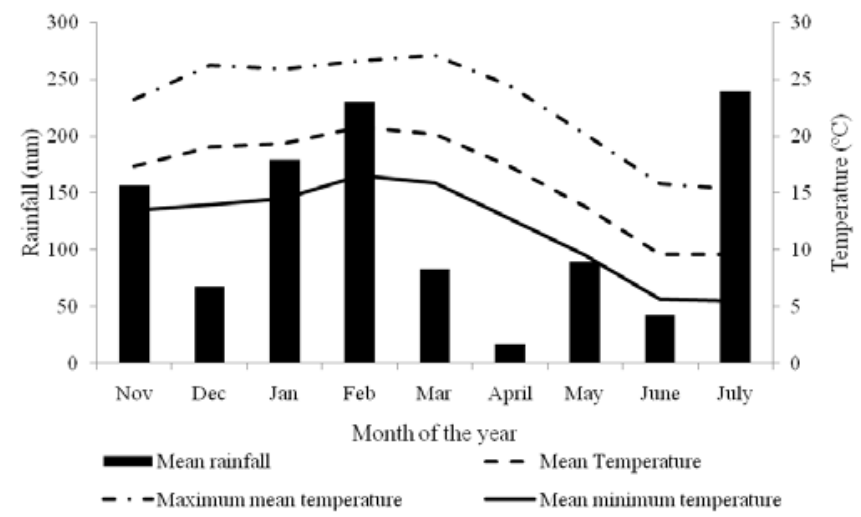

Figure 1 - Mean temperature (minimum, mean and maximum) and mean rainfall during the experimental period.
The experiment was completely randomized with $2 \times 2$ factorial arrangement, and was replicated three times. Thus, there were a total of 12 experimental units, each measuring $196 \mathrm{~m}^{2}$. Treatments consisted of two frequencies (time needed for the canopy to attain 95 to 98\% light interception during regrowth) and two defoliation intensities (10 and $15 \mathrm{~cm}$ post-grazing heights).

Prior to establishing the treatments, no grazing occurred, and the grass was mowed to approximately $15 \mathrm{~cm}$ in height. This was performed first in the end of December 2008 and then again in the beginning of January 2009, when treatments reached the desired light interception level. The treatments were maintained until the second half of May, permitting measurements to be made in two different seasons (summer and fall). Texel sheep (live weight of approximately $30 \mathrm{~kg}$, provided by the UDESC/CAV Animal and Food Production Department) were used as the grazers. The number of animals used in each grazing cycle was calculated so that grass grazing down would last no longer than one day by the mobgrazing technique (Gildersleeve et al., 1987). Animals merely served as defoliating agents, and they were not subjected to any assessments. Grasses received $150 \mathrm{~kg} / \mathrm{ha} \mathrm{N}$ from urea in fractions corresponding to each grazing cycle throughout the study.

Light interception and leaf area index (LAI) were measured twice each week at the onset of the regrowth period and every two days after reaching 90\% light interception until achieving the 95 and $98 \%$ light interception goals. In each experimental unit, an ACCUPAR ${ }^{\circledR}$ model LP 80 (Decagon Devices, USA) canopy analyzer was used to perform readings at six random points that were representative of the average state of the grasses at the time of sampling. One reading was performed above the canopy, and five were performed at ground level at each sampling site. Canopy height was measured in the same frequency as the light interception assessments. Fifty readings per unit were taken during each assessment session using a sward stick (Barthram, 1985) along five transects (10 points per transect), following a zigzag pattern.

To assess forage accumulation and morphological composition, two samples were taken per unit using a $50-\times 50$-cm quadrat. Plants were clipped every $5 \mathrm{~cm}$ down to ground level. This procedure was systematically performed before and after grazing. After stratified clipping, all collected materials were separated into fractions containing leaves, stems, dead plant material and invasive species. Finally, after all of the materials were separated, they were dried in a convection oven at $65^{\circ} \mathrm{C}$ for 48 hours then weighed for estimation of dry matter (DM). The results were grouped by season (summer and autumn); grazing 
cycles in all experimental units until March 252009 were grouped together in the summer and the remainder, in the autumn.

The data were analyzed using the MIXED procedure of the SAS $^{\circledR}$ statistical package (Statistical Analyses System, version 8.2). Covariance matrix selection was made according to the Akaike criterion (AIC) (Wolfinger, 1993). Thus, the effects of the main causes of variation (light interception, post-grazing height and time of year, and the interactions between them) could be detected. T-tests were used to compare means between treatments at the $5 \%$ significance level.

\section{Results and Discussion}

Because the interval between grazing cycles was defined as a function of two light interception levels, the number of grazing cycles was expected to vary between the treatments. Thus, more frequent (95\% light interception) and less severe (15 cm post-grazing height) grazing comprised five cycles. More frequent (95\% light interception) and more severe $(10 \mathrm{~cm})$ grazing comprised four cycles, as did less frequent (98\% light interception) and less severe (15 cm) grazing. Less frequent (98\% light interception) and more severe $(10 \mathrm{~cm})$ grazing comprised only three cycles.

During the pre-grazing period, forage mass was only affected by the time of year $(\mathrm{P}<0.05)$, and higher values were recorded in the fall (4,160 kg/ha DM) compared with summer (3,390 kg/ha DM). However, post-grazing forage mass varied as a function of light interception $(\mathrm{P}<0.05)$, post-grazing height $(\mathrm{P}<0.05)$, time of year $(\mathrm{P}<0.05)$ and the interaction between post-grazing height and time of year $(\mathrm{P}<0.05)$. In general, grasses managed with $95 \%$ light interception exhibited less post-grazing forage mass (average of $2,370 \mathrm{~kg} / \mathrm{ha} \mathrm{DM}$ ) compared with grasses managed with $98 \%$ light interception (average of 2,830 kg/ha DM). The interaction suggests that post-grazing forage mass increased between summer and fall, but that this effect was more pronounced when grasses were managed at $15 \mathrm{~cm}$ post-

Table 1 - Post- grazing herbage mass (kg/ha DM) in Aruana Guinea swards subjected to rotational grazing managements in two seasons of the year

\begin{tabular}{lcc}
\hline & \multicolumn{2}{c}{ Post-grazing height $(\mathrm{cm})$} \\
\cline { 2 - 3 } Season of the year & 10 & 15 \\
\hline Summer & $1,876 \mathrm{aB}(141.8)$ & $2,177 \mathrm{aB}(141.8)$ \\
Fall & $2,645 \mathrm{bA}(141.8)$ & $3,693 \mathrm{aA}(141.8)$ \\
\hline $\begin{array}{l}\text { Means followed by the same lowercase letter in rows and upper case letters in } \\
\text { columns are not different }(\mathrm{P}>0.05) . \text { Numbers in parentheses correspond to the } \\
\text { standard error of the mean. }\end{array}$
\end{tabular}

grazing height (Table 1). There were no differences in postgrazing forage mass when grasses were managed with 10 and $15 \mathrm{~cm}$ post-grazing heights in the summer (Table 1 ).

Grass internode elongation occurred at the onset of the reproductive period (fall), possibly contributing to the higher fraction of stems in the forage mass during this time. Similarly, Carnevalli et al. (2006) found an increase in the proportion of stems during the vegetative and reproductive stages in pre- and post-grazing forage mass with intermittent stocking and $100 \%$ pre-grazing light interception compared with 95\% light interception in Mombasa-grass swards. Additionally, Santos et al. (1999) observed a significant increase in residue forage mass along with an increase in the resting period at $100 \%$ light interception in Tanzania-grass under rotational grazing.

Pre-grazing height was relatively homogeneous in grasses managed with 95\% light interception but not when grazing cycles were less frequent (98\% light interception). During pre-grazing, the canopy height was influenced by light interception $(\mathrm{P}<0.05)$, post-grazing height $(\mathrm{P}<0.05)$, time of year $(\mathrm{P}<0.05)$, the interaction between light interception and post-grazing height $(\mathrm{P}<0.05)$ and the interaction between light interception and time of year $(\mathrm{P}<0.05)$. Pre-grazing height increased when grasses were managed with $95 \%$ light interception and $10 \mathrm{~cm}$ post-grazing height. The same was observed for less frequent (98\% light interception) grazing cycles, and this effect was more pronounced in grasses managed with $98 \%$ light interception and $10 \mathrm{~cm}$ post-grazing height (Table 2).

Higher pre-grazing heights were observed in grasses managed with $98 \%$ light interception during both growing seasons. The light interception $\times$ time of year interaction showed that pre-grazing height decreased between summer and fall at both frequencies tested; however, the effect was more pronounced when grasses were managed with $98 \%$ light interception (Table 2).

Table 2 - Pre-grazing sward height $(\mathrm{cm})$ in Aruana Guinea grass swards subjected to rotational grazing managements in two seasons of the year

\begin{tabular}{|c|c|c|}
\hline \multirow[b]{2}{*}{ Post-grazing height (cm) } & \multicolumn{2}{|c|}{ Sward light interception (\%) } \\
\hline & 95 & 98 \\
\hline 10 & $32.4 \mathrm{Bb}(0.65)$ & $45.2 \mathrm{Aa}(0.73)$ \\
\hline 15 & $30.7 \mathrm{Ab}(0.65)$ & 39.3Ва (0.65) \\
\hline & \multicolumn{2}{|c|}{ Sward light interception (\%) } \\
\hline Season of the year & 95 & 98 \\
\hline Summer & 32.9Ab (0.65) & $47.1 \mathrm{aA}(0.65)$ \\
\hline Autumn & $30.0 \mathrm{Bb}(0.65)$ & $37.4 \mathrm{aB}(0.73)$ \\
\hline
\end{tabular}

R. Bras. Zootec., v.41, n.4, p.905-913, 2012 
Canopy pre-grazing height was also stable in a study on Mombasa-grass by Da Silva et al. (2009), who observed that pre-grazing heights were 90 and $115 \mathrm{~cm}$ for 95 and $100 \%$ light interception treatments, respectively. This suggests a potential for the development and use of management practices based on goals related to grass conditions. Likewise, Hack et al. (2007) compared Mombasa-grass swards under an intermittent stocking regime managed with two different pre-grazing heights $(140$ and $90 \mathrm{~cm}$ ) and two post-grazing heights ( 0 and $50 \mathrm{~cm}$ ), showing that the lower pre-grazing height positively influenced canopy characteristics and cow milk production. The consistent pre-grazing height results measured for Aruana Guineagrass suggest a promising use for pre-grazing canopy height as a practical, simple and reliable guide exhibiting remarkable uniformity and consistency regardless of the time of the year, postgrazing height and plant phenological state (Sbrissia \& Da Silva, 2001; Vilela et al., 2005; Pereira et al., 2010). However, it should be stressed that height determination must be associated with the physiological and cophysiological parameters of swards to be useful as a management tool.

The timing of animal removal was determined by postgrazing height in an attempt to keep residual forage mass structure under control. Residual forage mass quantity and quality are of the greatest importance for regrowth of the following grazing cycle. Post-grazing height was influenced by light interception $(\mathrm{P}<0.05)$, post-grazing height $(\mathrm{P}<0.05)$, time of year $(\mathrm{P}<0.05)$, the interaction between light interception and time of year $(\mathrm{P}<0.05)$ and the interaction between post-grazing height and time of year $(\mathrm{P}<0.05)$.

In general, the goal of maintaining the post-grazing height was only attained when grasses were managed with 95\% light interception and $15 \mathrm{~cm}$ post-grazing height (Table 3). Post-grazing height increased between summer and fall in grasses managed with 95 and 98\% light interception and in grasses managed with 10 and $15 \mathrm{~cm}$

Table 3 - Post-grazing sward height $(\mathrm{cm})$ in Aruana Guinea grass swards subjected to rotational grazing managements in two seasons of the year

\begin{tabular}{lcc}
\hline & \multicolumn{2}{c}{ Sward light } \\
\cline { 2 - 3 } Season of the year & 95 & 98 \\
\hline Summer & $14.4 \mathrm{bB}(0.43)$ & $18.0 \mathrm{aB}(0.43)$ \\
Fall & $15.2 \mathrm{bA}(0.43)$ & $20.9 \mathrm{aA}(0.48)$ \\
& \multicolumn{3}{c}{ Post-grazing } & sward height $(\mathrm{cm})$ \\
Season of the year & 10 & 15 \\
Summer & $14.5 \mathrm{bB}(0.43)$ & $17.1 \mathrm{aA}(0.43)$ \\
Fall & $17.8 \mathrm{aA}(0.48)$ & $17.7 \mathrm{aA}(0.43)$ \\
\hline
\end{tabular}

Means followed by the same lowercase letter in rows and upper case letters in columns are not different $(\mathrm{P}>0.05)$. Numbers in parentheses correspond to the standard error of the mean. residue (Table 3). More frequent grazing cycles (95\% light interception) were more efficient in maintaining the $15 \mathrm{~cm}$ post-grazing height goal, as were grasses managed with $15 \mathrm{~cm}$ residue.

Post-grazing conditions were maintained during both growth seasons for the 15 -cm post-grazing height (Table 3 ). This was not achieved with more severe grazing cycles $(10 \mathrm{~cm})$, where an increase in post-grazing height was observed between summer and fall (Table 3). These results are in accordance with the results found by Zanini et al. (2010), who showed that approximately $90 \%$ of all stems in forage plants subjected to intermittent stocking were below $50 \%$ of the initial height, thus making foraging and ingestion more difficult for the sheep.

The LAI was influenced by light interception $(\mathrm{P}<0.05)$, post-grazing height $(\mathrm{P}<0.05)$, time of year $(\mathrm{P}<0.05)$, the interaction between lighting interception and time of year $(\mathrm{P}<0.05)$ and the interaction between post-grazing height and time of year $(\mathrm{P}<0.05)$. Higher pre-grazing LAIs were observed in the summer and with use of lower-frequency (98\% lighting interception) and higher-severity $(10 \mathrm{~cm})$ grazing. Pre-grazing LAI decreased between summer and fall, and this effect was more pronounced in grasses managed with $15 \mathrm{~cm}$ post-grazing height in the fall (Table 4).

Leaf area index increased as a function of grass height. This result agrees with Penning \& Parsons (1991), who observed higher LAI values in Lolium perenne grazed by sheep when grasses were kept higher. In the post-grazing period, LAI was only affected by post-grazing height $(\mathrm{P}<0.05)$ and time of the year $(\mathrm{P}<0.05)$. In general, higher LAI was observed with $15 \mathrm{~cm}$ post-grazing height (1.7) compared with $10 \mathrm{~cm}$ post-grazing height (1.2) and in summer (1.6) compared with the fall (1.3). Similarly to the results observed in this study, which measured higher residual LAIs in grasses managed with $15 \mathrm{~cm}$ post-grazing height, Zimmer (1999) assessed Aruana and Vencedor Guineagrass swards subjected to low and high grazing residue $(3,600$ and

Table 4 - Pre-grazing leaf area index (LAI) in Aruana Guinea grass swards subjected to rotational grazing managements in two seasons of the year

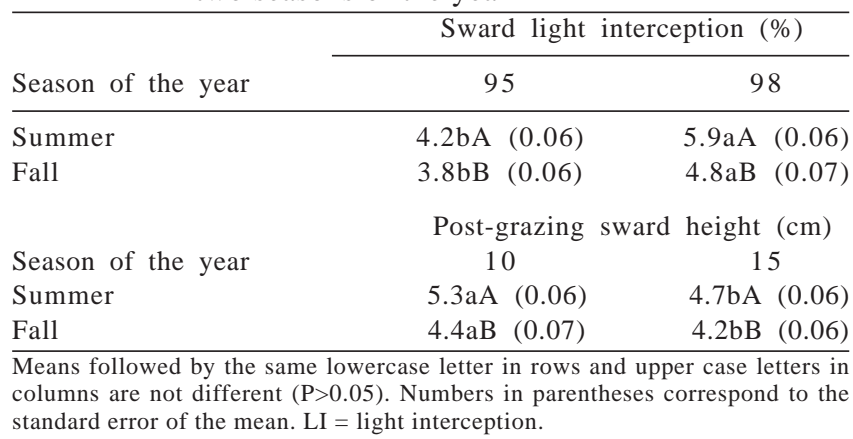

R. Bras. Zootec., v.41, n.4, p.905-913, 2012 
4,500 kg/ha residual DM, respectively) and concluded that residual LAI increased in high-residue grazing treatments at all harvesting time periods. Humphreys (1991) suggested that the optimal LAI range is between 3 and 5 for Panicum maximum and that growth decreases with lower LAI values. In this study, LAI varied between 4.2 in the summer and 3.8 in the fall, when grasses were managed with 95\% lighting interception, and between 4.7 in the summer and 4.2 in the fall, when grasses were managed with $15 \mathrm{~cm}$ post-grazing height. However, it should be clarified that the values found for LAI in this study do not necessary correspond to the exact values ones, since that LAI measurements can be overestimated, once an indirect measurement method was used to estimate them (Sbrissia \& Da Silva, 2008).

Post-grazing light interception was affected by postgrazing height $(\mathrm{P}<0.05)$ and the interaction between light interception and post-grazing height $(\mathrm{P}<0.05)$. The interaction demonstrated that light interception had no effect on pre-grazing height, and that management with $15 \mathrm{~cm}$ post-grazing height increased the post-grazing light interception percentage only when combined with $98 \%$ pre-grazing light interception (Table 5).

The morphological composition of the sward was strongly affected by the treatments. Only light interception $(\mathrm{P}<0.05)$ had an effect on pre-grazing leaf mass. The highest values were observed in grasses managed with 95\% light interception (average of 1,930 kg/ha DM), and the lowest values were observed in grasses managed with 98\% light interception (average of 1,630 kg/ha DM). Only season of the year had an effect on post-grazing leaf mass $(\mathrm{P}<0.05)$. The highest values were observed in the summer (average of $740 \mathrm{~kg} / \mathrm{ha} \mathrm{DM}$ ), and the lowest values were observed in the fall (average of $580 \mathrm{~kg} / \mathrm{ha} \mathrm{DM}$ ). The proportions of leaf blades in pre- and post-grazing forage masses are similar to the results obtained by Mello \& Pedreira (2004) and Barbosa et al. (2007). Likewise, according to Trindade et al. (2007), grazing management allows pastoral environments to develop that favor consumption of morphological components with high nutritional value.

Table 5 - Post-grazing light interception (\%) in Aruana Guinea grass swards subjected to rotational grazing managements in two seasons of the year

\begin{tabular}{|c|c|c|}
\hline \multirow[b]{2}{*}{ Post-grazing height $(\mathrm{cm})$} & \multicolumn{2}{|c|}{ Sward light interception (\%) } \\
\hline & 95 & 98 \\
\hline 10 & $59.2 \mathrm{aA} \quad(1,5)$ & $55.1 \mathrm{aB}(1.7)$ \\
\hline 15 & $60.4 \mathrm{aA}(1.5)$ & $64.3 \mathrm{aA} \quad(1.5)$ \\
\hline
\end{tabular}

The presence of stems in the forage canopy was the primary factor that modified grass structure.

The management techniques in this experiment defined the structure of the forage canopy by allowing for the control or development of stems. Pre-grazing stem mass was affected by light interception $(\mathrm{P}<0.05)$, post-grazing height $(\mathrm{P}<0.05)$, time of year $(\mathrm{P}<0.05)$, the interaction between light interception and the time of year $(\mathrm{P}<0.05)$ and the interaction of post-grazing height and time of the year $(\mathrm{P}<0.05)$. In general, pre-grazing stem mass increased between summer and fall, and this effect was more pronounced when grasses were managed with $98 \%$ light interception and $15 \mathrm{~cm}$ post-grazing height (Table 6).

Post-grazing stem mass was affected by light interception $(\mathrm{P}<0.05)$, post-grazing height $(\mathrm{P}<0.05)$, time of year $(\mathrm{P}<0.05)$ and the interaction between post-grazing height and time of year $(\mathrm{P}<0.05)$. In general, lower postgrazing stem mass was observed in grasses managed with 95\% light interception (average of $904 \mathrm{~kg} / \mathrm{ha} \mathrm{DM}$ ) compared with grasses managed with 98\% light interception (average of $1,127 \mathrm{~kg} / \mathrm{ha} \mathrm{DM})$. The interaction was characterized by an increase of post-grazing stem mass between summer and fall, especially when grasses were managed with $15 \mathrm{~cm}$ postgrazing height (Table 7).

Fall was the season that yielded the highest pre- and post-grazing stem mass (Tables 6 and 7), probably because stem mass increased continuously from the onset of the

Table 6 - Pre-grazing stem mass (kg/ha DM) in Aruana Guinea grass swards subjected to rotational grazing managements in two seasons of the year

\begin{tabular}{lcr}
\hline & \multicolumn{2}{c}{ Sward light interception (\%) } \\
\cline { 2 - 3 } Season of the year & 95 & 98 \\
\hline Summer & $718 \mathrm{aB}(67.4)$ & $720 \mathrm{aB}(67.4)$ \\
Fall & $1,017 \mathrm{bA}(67.4)$ & $1,355 \mathrm{aA}(67.4)$ \\
& Post-grazing height (cm) \\
Season of the year & 10 & 15 \\
Summer & $724 \mathrm{aB}(67.4)$ & $714 \mathrm{aB}(67.4)$ \\
Fall & $1,038 \mathrm{aA}(67.4)$ & $1,333 \mathrm{aA}(67.4)$ \\
$\begin{array}{l}\text { Means followed by the same lowercase letter in rows and upper case letters in } \\
\text { columns are not different }(\mathrm{P}>0.05) \text {. Numbers in parentheses correspond to the } \\
\text { standard error of the mean. }\end{array}$
\end{tabular}

Table 7 - Post-grazing stem mass (kg/ha DM) in Aruana Guinea grass swards subjected to rotational grazing managements in two seasons of the year

\begin{tabular}{lcr}
\hline & \multicolumn{2}{c}{ Post-grazing height (cm) } \\
\cline { 2 - 3 } Season of the year & 10 & 15 \\
\hline Summer & 636aB (53,1) & 777aB (53,1) \\
Fall & $1,135 \mathrm{aA} \mathrm{(53.1)}$ & $1,432 \mathrm{aA}(53.1)$ \\
\hline
\end{tabular}

Means followed by the same lowercase letter in rows and upper case letters in columns are not different $(\mathrm{P}>0.05)$. Numbers in parentheses correspond to the standard error of the mean. 
study. This was particularly so in grasses managed with 98\% light interception and $15 \mathrm{~cm}$ post-grazing height. Longer grazing intervals provided more opportunity for the plants to replenish reserves spent in the recovery of the canopy. Stem elongation can occur if the interval is sufficiently long for the canopy to intercept virtually all incident light (Mello \& Pedreira, 2004), particularly in tropical forage grasses. This can alter the patterns of accumulation and can lead to an increase in post-grazing forage mass (Table 1 ). This effect is probably due to increased mass of individual tillers (Sbrissia \& Da Silva, 2001).

Pre-grazing dead plant material mass was affected by light interception $(\mathrm{P}<0.05)$, post-grazing height $(\mathrm{P}<0.05)$, time of year $(\mathrm{P}<0.05)$, the interaction between light interception and time of year $(\mathrm{P}<0.05)$ and the interaction between postgrazing height and time of year $(\mathrm{P}<0.05)$. Pre-grazing dead plant material mass increased between summer and fall, and this effect was more pronounced when grasses were managed with $98 \%$ light interception and $15 \mathrm{~cm}$ post-grazing height (Table 8).

Post-grazing DM was affected by LI $(\mathrm{P}<0.05)$, postgrazing height $(\mathrm{P}<0.05)$, time of year $(\mathrm{P}<0.05)$, the interaction between $\mathrm{LI}$ and time of year $(\mathrm{P}<0.05)$ and the interaction between post-grazing height and time of year $(\mathrm{P}<0.05)$. Post-grazing dead plant material mass increased between summer and fall, especially when grasses were managed with 98\% LI and $15 \mathrm{~cm}$ post-grazing height (Table 9).

Dead plant material mass was higher in the fall and in the post-grazing period. This is potentially explained by the accumulation of this component in swards since the onset of the assessment (January). Moreover, tissue turnover is higher during the hot and rainy season (summer); thus, both tiller survival and mortality are accelerated (Moreira et al., 2009). However, the tendency for dead plant material mass accumulation is higher at the beginning of the fall because leaf and tiller growth becomes limited by environmental conditions such as temperature and radiation. It should be

Table 8 - Pre-grazing dead material mass (kg/ha DM) in Aruana Guinea grass swards subjected to rotational grazing managements in two seasons of the year

\begin{tabular}{|c|c|c|}
\hline \multirow[b]{2}{*}{ Season of the year } & \multicolumn{2}{|c|}{ Sward light interception (\%) } \\
\hline & 95 & 98 \\
\hline Summer & 236aB (40.6) & $300 \mathrm{aB}(40.6)$ \\
\hline Fall & 548bA (40.6) & $811 \mathrm{aA}(40.6)$ \\
\hline & \multicolumn{2}{|c|}{ Post-grazing (cm) } \\
\hline Season of the year & 10 & 15 \\
\hline Summer & $266 \mathrm{aB}(40.6)$ & $270 \mathrm{aB}(40.6)$ \\
\hline Fall & 521aA (40.6) & 838aA (40.6) \\
\hline
\end{tabular}

Means followed by the same lowercase letter in rows and upper case letters in columns are not different $(\mathrm{P}>0.05)$. Numbers in parentheses correspond to the standard error of the mean. noted that the transition from the vegetative to the reproductive stage also contributes to increased dead plant material mass because the leaf and tiller growth becomes limited by physiological conditions such as the supply of photoassimilates for new tissue formation and development.

The mass of pre-grazing invasive species was only affected by time of year $(\mathrm{P}<0.05)$, and higher values were observed in the fall (average of $480 \mathrm{~kg} / \mathrm{ha} \mathrm{DM}$ ) compared with the summer (average of $300 \mathrm{~kg} / \mathrm{ha} \mathrm{DM}$ ). The greater mass of invasive species in the fall is mainly because Aruana Guineagrass is a tropical plant: it is less competitive against invasive plants with lower temperatures.

Grazing management differentially affected the pregrazing proportions of leaf blades, stems, dead plant material and invaders. In general, only light interception $(\mathrm{P}<0.05)$ and time of year $(\mathrm{P}<0.05)$ influenced pre-grazing leaf proportions. A higher pre-grazing leaf proportion was observed in grasses managed with 95\% light interception (54.3\%) compared with 98\% light interception (47.7\%). A greater pre-grazing leaf proportion was observed in the summer (56.0\%) compared with the fall (45.9\%). Postgrazing leaf proportions were also affected by light interception $(\mathrm{P}<0.05)$ and time of year $(\mathrm{P}<0.05)$. In general, a higher proportion of post-grazing leaves was observed in grasses managed with 95\% light interception (31.3\%) compared with $98 \%$ light interception (25.3\%). Post-grazing leaf proportions were higher in the summer (38.0\%) compared with the fall (18.6\%). The lowest pre- and postgrazing proportions of leaves occurred in grasses managed with $98 \%$ light interception. The main consequence of this management type is that strong competition for light might decrease the leaf layer in the canopy profile and might increase stem mass (Tables 6 and 7) and dead plant material (Tables 8 and 9), which is typical of tropical gramineous plants during blooming (fall).

The pre-grazing proportion of stems was affected by light interception $(\mathrm{P}<0.05)$, post-grazing height $(\mathrm{P}<0.05)$,

Table 9 - Post-grazing dead material mass (kg/ha DM) in Aruana Guinea grass swards subjected to rotational grazing managements in two seasons of the year

\begin{tabular}{lcc}
\hline & \multicolumn{2}{c}{ Sward light interception (\%) } \\
\cline { 2 - 3 } Season of the year & 95 & 98 \\
\hline Summer & 180aB (59.7) & 315aB (59.7) \\
Fall & 588bA (59.7) & $985 \mathrm{aA}(59.7)$ \\
& Post-grazing height (cm) \\
Season of the year & 10 & 15 \\
Summer & 242aB (59.7) & 253aB (59.7) \\
Fall & 628aA (59.7) & 985aA (59.7) \\
\hline
\end{tabular}

Means followed by the same lowercase letter in lines and upper case letters in columns are not different $(\mathrm{P}>0.05)$. Numbers in parentheses correspond to the standard error of the mean. 
time of year $(\mathrm{P}<0.05)$ and the interaction between light interception and time of year $(\mathrm{P}<0.05)$. In general, a higher pre-grazing proportion of stems was observed in grasses managed with $15 \mathrm{~cm}$ post-grazing height (27.8\%) compared with $10 \mathrm{~cm}$ (25.0\%). The interaction revealed an increase of pre-grazing stem proportions between summer and fall, especially when management of grass was less frequent (98\% light interception) (Table 10).

The post-grazing proportion of stems was affected by light interception $(\mathrm{P}<0.05)$, post-grazing height $(\mathrm{P}<0.05)$ and time of year $(\mathrm{P}<0.05)$. In general, a higher post-grazing proportion of stems was observed in grasses managed with 98\% light interception (41.8\%) compared with 95\% light interception (36.5\%). Post-grazing stem proportions were lower (37.3\%) when grasses were managed more severely $(10 \mathrm{~cm})$ compared with grasses managed with $15 \mathrm{~cm}$ postgrazing height (40.1\%). The post-grazing proportion of stems was higher (43.5\%) in the fall compared with the summer (34.9\%). In grasses managed with $15 \mathrm{~cm}$ postgrazing height, the absolute amounts of plant stems were similar to severe grazing cycles $(10 \mathrm{~cm})$ despite higher preand post-grazing stem proportions, which indicates effective control of stem elongation by these treatments, especially when combined with $95 \%$ light interception. The rate of recovery for pre-grazing conditions after defoliation is an important trait in grass production systems (Montagner et al., 2011) because it leads to increasingly earlier use of grass, which gives rise to younger and easier-to-harvest stems and does not lead to high stem elongation rates (Carnevalli et al., 2006). This trait was observed in grasses managed with 95\% light interception (Table 10) and less-severe postgrazing height $(15 \mathrm{~cm})$. The defoliation strategy with $95 \%$ light interception resulted in significantly lower post-grazing forage mass because the higher defoliation frequency led to shorter intervals between grazing cycles (Pedreira et al., 2009). However, this condition was compensated by the greater number of grazing cycles occurring in sites managed with 95\% light interception, probably resulting in production of younger forage with better nutritional value.

Table 10 - Pre-grazing stem proportion (\%) in Aruana Guinea grass swards subjected to rotational grazing managements in two seasons of the year

\begin{tabular}{lcc}
\hline & \multicolumn{2}{c}{ Sward light interception (\%) } \\
\cline { 2 - 3 } Season of the year & 95 & 98 \\
\hline Summer & 23.9bA $(0.71)$ & $26.5 \mathrm{aB}(0.71)$ \\
Fall & $24.7 \mathrm{bA}(0.71)$ & $30.5 \mathrm{aA}(0.71)$ \\
\hline
\end{tabular}

Means followed by the same lowercase letter in rows and upper case letters in columns are not different $(\mathrm{P}>0.05)$. Numbers in parentheses correspond to the standard error of the mean.
The proportion of pre-grazing dead plant material was affected by light interception $(\mathrm{P}<0.05)$, time of the year $(\mathrm{P}<0.05)$ and the interaction between post-grazing height and time of the year $(\mathrm{P}<0.05)$. In general, the proportion of pre-grazing dead plant material was higher in grasses managed with 98\% light interception (14.2\%) compared with 95\% light interception (10.1\%). The interaction revealed that the proportion of pre-grazing dead plant material increased between summer and fall, particularly so in grasses managed with $15 \mathrm{~cm}$ post-grazing height (Table 11).

The proportion of post-grazing dead plant material was affected by light interception $(\mathrm{P}<0.05)$, time of year $(\mathrm{P}<0.05)$ and the interaction between light interception and postgrazing height $(\mathrm{P}<0.05)$. A higher proportion of post-grazing dead plant material was observed in the fall (24.1\%), compared with the summer (11.2\%). This interaction showed that the proportion of post-grazing dead plant material decreased in grasses managed with 95\% light interception and $15 \mathrm{~cm}$ post-grazing height but not in less-frequent grazing cycles (98\% light interception), particularly when grasses were managed with $98 \%$ light interception and $15 \mathrm{~cm}$ post-grazing height (Table 12).

The pre-grazing proportion of invaders was affected by light interception $(\mathrm{P}<0.05)$, time of year $(\mathrm{P}<0.05)$ and the interaction between light interception and post-grazing height $(\mathrm{P}<0.05)$. In general, the pre-grazing proportion of invaders was lower in the summer (9.4\%) compared with the fall (14.4\%). There were no differences in the pre-grazing proportion of invaders at both post-grazing heights examined when grasses were managed with 95\% light interception

Table 11 - Pre-grazing dead material proportion (\%) in Aruana Guinea grass swards subjected to rotational grazing managements in two seasons of the year

\begin{tabular}{|c|c|c|}
\hline \multirow[b]{2}{*}{ Season of the year } & \multicolumn{2}{|c|}{ Post-grazing height $(\mathrm{cm})$} \\
\hline & 10 & 15 \\
\hline Summer & 9.9aB (1.23) & $7.8 \mathrm{bB}(1.23)$ \\
\hline Fall & $12.7 \mathrm{bA}(1.23)$ & 18.3aA (1.23) \\
\hline
\end{tabular}

Table 12 - Post-grazing dead material proportion (\%) in Aruana Guinea grass swards subjected to rotational grazing managements in two seasons of the year

\begin{tabular}{|c|c|c|}
\hline \multirow[b]{2}{*}{ Post-grazing height (cm) } & \multicolumn{2}{|c|}{ Sward light interception (\%) } \\
\hline & 95 & 98 \\
\hline 10 & 17.2aA (0.97) & $17.5 \mathrm{aB}(0.97)$ \\
\hline 15 & $14.3 \mathrm{bB}(0.97)$ & $21.5 \mathrm{aA}(0.97)$ \\
\hline
\end{tabular}

R. Bras. Zootec., v.41, n.4, p.905-913, 2012 
(Table 12), suggesting that more frequently managed (95\% light interception) Aruana Guineagrass exhibits greater competition against invasive plants. The pre-grazing proportion of invaders decreased when grasses were managed with 98\% light interception and $15 \mathrm{~cm}$ post-grazing height (Table 13).

In this study, time of the year was a striking characteristic affecting forage accumulation, reflecting the typical seasonal production of tropical gramineous species (Pedreira \& Mattos, 1981). The DM accumulation rate (kg/ha/day DM) was affected by light interception $(\mathrm{P}<0.05)$, post-grazing height $(\mathrm{P}<0.05)$, time of the year $(\mathrm{P}<0.05)$, the interaction between light interception and post-grazing height $(\mathrm{P}<0.05)$ and the interaction between post-grazing height and time of the year $(\mathrm{P}<0.05)$. There was no difference in the rate of $\mathrm{DM}$ accumulation between post-grazing height treatments when grasses were managed with 95\% light interception (Table 14).

When grasses were managed with 98\% light interception, the rate of DM accumulation increased in the treatment with $15 \mathrm{~cm}$ post-grazing height compared with $10 \mathrm{~cm}$ post-grazing height (Table 14 ). There was no difference in the rate of dry mass accumulation in the summer when grasses were managed with $10 \mathrm{~cm}$ post-grazing height (Table 14). Dry mass accumulation rate decreased between summer and fall; this effect was more pronounced when grasses were managed with $15 \mathrm{~cm}$ post-grazing height (Table 14).

Table 13 - Pre-grazing invaders proportion (\%) in Aruana Guinea grass swards subjected to rotational grazing managements in two seasons of the year

\begin{tabular}{lcc}
\hline & \multicolumn{2}{c}{ Sward light } \\
\cline { 2 - 3 } Post-grazing height $(\mathrm{cm})$ & 95 & 98 \\
\hline 10 & $16.6 \mathrm{aA}(2.23)$ & $21.0 \mathrm{aA}(2.23)$ \\
15 & $17.2 \mathrm{aA}(2.23)$ & $14.4 \mathrm{bB}(2.23)$ \\
\hline $\begin{array}{l}\text { Means followed by the same lowercase letter in rows and upper case letters in } \\
\text { columns are not different }(\mathrm{P}>0.05) \text {. Numbers in parentheses correspond to the } \\
\text { standard error of the mean. }\end{array}$
\end{tabular}

Table 14 - Forage accumulation rate $\left(\mathrm{kg} / \mathrm{ha}_{\text {day }}{ }^{-1} \mathrm{DM}\right)$ in Aruana Guinea grass swards subjected to rotational grazing managements in two seasons of the year

\begin{tabular}{ccc}
\hline & \multicolumn{2}{c}{ Sward light } \\
\cline { 2 - 3 } Post-grazing height $(\mathrm{cm})$ & 95 & 98 \\
\hline 10 & $66.0 \mathrm{aA}(3.3)$ & $45.0 \mathrm{bB}(3.3)$ \\
15 & $75.0 \mathrm{aA}(3.3)$ & $71.0 \mathrm{aA}(3.3)$ \\
& Season of & the year \\
Post-grazing height $(\mathrm{cm})$ & Summer & Fall \\
10 & 59.0aB (3.3) & 52.0aA (3.3) \\
15 & $90.0 \mathrm{aA}(3.3)$ & $55.0 \mathrm{bA}(3.3)$ \\
\hline
\end{tabular}

Means followed by the same lowercase letter in rows and upper case letters in columns are not different $(\mathrm{P}>0.05)$. Numbers in parentheses correspond to the standard error of the mean.
At the onset of the study (summer), the dry mass accumulation rate primarily responded to variations in light interception during the post-grazing period (Table 5). In the fall, dry mass accumulation rates were limited by climatic conditions, such as temperature and radiation, and by physiological conditions, such as blooming. Moreover, higher stem mass (Tables 6 and 7) and dead plant material mass (Tables 8 and 9) during fall reduced the net accumulation in these treatments (Cândido et al., 2005; Santos et al., 2006). Pre- and post-grazing forage masses were lower in grasses managed with 95\% light interception, whereas the pre- and post-grazing leaf proportions were higher and the stem proportions were lower (Table 10), as was dead plant material (Tables 11 and 12). Effects of treatments on dry mass accumulation rate were more evident in the summer, reaching up to $90 \mathrm{~kg} / \mathrm{ha} /$ day DM in grasses managed with $15 \mathrm{~cm}$ post-grazing height. Grasses managed with $15 \mathrm{~cm}$ post-grazing height notably accumulated dry mass faster in the summer and recovered faster from defoliation despite a higher pre-grazing proportion of stems (2.8\% greater) compared with grasses managed with $10 \mathrm{~cm}$ post-grazing height.

\section{Conclusions}

Managing Aruana Guineagrass swards with grazing at 95\% incident light interception (30 cm high) and having it grazed to $15 \mathrm{~cm}$ post-grazing height ensures greater rate of dry mass accumulation and better control of stem elongation.

\section{Acknowledgements}

The authors would like to thank FAPESC (Fundação de Amparo a Pesquisa e Inovação do Estado de Santa Catarina), for funding this research, and the members of NUPEP (Núcleo de Pesquisa em Pastagens - UDESC/CAV), for their help in field measurements.

\section{References}

AMARAL, M.F. Estruturas de pasto para elevadas velocidades de ingestão: um modelo para sistemas leiteiros. 2009. $173 \mathrm{f}$. Dissertação (Mestrado em Zootecnia) - Universidade Federal do Rio Grande do Sul, Porto Alegre.

BARBOSA, R.A.; NASCIMENTO JÚNIOR, D.; EUCLIDES, V.P.B. et al. Capim-Tanzânia submetido a combinações entre intensidade e freqüência de pastejo. Pesquisa Agropecuária Brasileira, v.42, p.329-340, 2007.

BARTHRAM, G.T. Experimental techniques: the HFRO sward stick. In: The Hill Farming Research Organization Biennial Report 1984/1985. Penicuik: HFRO, 1985. p.29-30.

BIRCHAM, J.S.; HODGSON, J. The influence of sward condition on rates of herbage growth and senescence in mixed sward under 
continuous stocking management. Grass and Forage Science, v.38, n.4, p.323-331, 1983.

BRAGA, H.J.; GHELLRE, R. Proposta de diferenciação climática para o Estado de Santa Catarina. In: CONGRESSO BRASILEIRO DE AGROMETEOROLOGIA, 11.; REUNIÃO LATINOAMERICANA DE AGROMETEOROLOGIA, 2., 1999. Florianópolis. Anais... Florianópolis: SBA, 1999. (CD-ROM).

CÂNDIDO, M.J.D.; GOMIDE, C.A.M.; ALEXANDRINO, E. et al. Morfofisiologia do dossel de Panicum maximum cv. Mombaça sob lotação intermitente com três períodos de descanso. Revista Brasileira de Zootecnia, v.34, n.2, p.406-415, 2005.

CANO, C.C.P.; CECATO, U.; CANTO, M.W. et al. Valor nutritivo do capim-Tanzânia (Panicum maximum Jacq. cv. Tanzânia) pastejado em diferentes alturas. Revista Brasileira de Zootecnia, v.33, n.6, p.1959-1968, 2004 (supl.2).

CARNEVALLI, R.A.; DA SILVA, S.C.; BUENO, A.A.O. et al. Herbage production and grazing losses in Panicum maximum cv. Mombaça under four grazing managements. Tropical Grasslands, v.40, p.165-176, 2006.

CHACON, E.; STOBBS, T.H. Influence of progressive defoliation of a grass sward on the eating behavior of cattle. Australian Journal of Agricultural Research, v.27, p.709-727, 1976.

CHAPMAN, D.F.; LEMAIRE, G. Morphogenetic and structural determinants of plant regrowth after defoliation. In: INTERNATIONAL GRASSLAND CONGRESS, 17., 1993, Australia. Proceedings... Australia: s.ed. 1993. p.95-104.

DA SILVA, S.C.; BUENO, A.A.O.; CARNEVALLI, R.A. et al. Sward structural characteristics and herbage accumulation of Panicum maximum cv. Mombaça subjected to rotational stoking managements. Scientia Agricola, v.66, n.1, p.8-19, 2009.

DAVIES, A.; EVANS, M.E.; EXLEY, J.K. Regrowth of perennial ryegrass as affected by simulated leaf sheaths. Journal of Agricultural Science, v.77, p.131-137, 1983.

EMPRESA BRASILEIRA DE PESQUISA AGROPECUÁRIA EMBRAPA. Sistema brasileiro de classificação de solos. 2.ed. Rio de Janeiro: Embrapa Solos, 2006. 306p.

GILDERSLEEVE, R.R.; OCUMPAUGH, W.R.; QUESENBERRY, K.H. et al. Mob-grazing of morphologically different Aeschynomene species. Tropical Grasslands, v.21, p.123-132, 1987.

HACK, E.C.; FILHO, A.B.; MORAES, A. et al. Características estruturais e produção de leite em pastos de capim-Mombaça (Panicum maximum Jacq.) submetidos a diferentes alturas de pastejo. Ciência Rural, v.37, p.218-222, 2007.

HODGSON, J. The significance of sward characteristics in the management of temperate sown pastures. In: INTERNATIONAL GRASSLAND CONGRESS, 15., 1985, Kyoto. Proceedings... Kyoto: Japanese Society of Grassland Science, 1985. p.63-66.

HODGSON, J.; DA SILVA, S.C. Options in tropical pasture management. In: REUNIÃO ANUAL DA SOCIEDADE BRASILEIRA DE ZOOTECNIA, 39., 2002, Recife. Proceedings... Brasília: Sociedade Brasileira de Zootecnia, 2002. p.180-202.

HUMPHREYS, L.R. Tropical pasture utilization. Cambridge: Cambridge University Press, 1991. 206p.

LACA, E.A.; LEMAIRE, G. Measuring sward structure. In: T'MANNETJE, L.; JONES, R.M. (Eds.) Field and laboratory methods for grassland and animal production research. New York: Cabi International, 2000. p.103-122.

MELLO, A.C.L.; PEDREIRA, C.G.S. Respostas morfológicas do capim-Tanzânia (Panicum maximum Jacq. cv. Tanzânia-1) irrigado à intensidade de desfolha sob lotação rotacionada. Revista Brasileira de Zootecnia, v.33, p.282-289, 2004.

MONTAGNER, D.B.; NASCIMENTO JÚNIOR, D.; SOUSA, B.M.L. et al. Morphogenetic and structural characteristics of tillers of guinea grass of different age and grazing severities. Revista Brasileira de Zootecnia, v.40, n.10, p.2105-2110, 2011. MOREIRA, L.M.; MARTUSCELLO, J.A.; FONSECA, D.M. et al. Perfilhamento, acúmulo de forragem e composição bromatológica do capim-braquiária adubado com nitrogênio. Revista Brasileira de Zootecnia, v.38, n.9, p.1675-1684, 2009.

PARSONS, A.J.; PENNING, P.D. The effect of duration of regrowth on photosynthesis, leaf death and average rate of growth in a rotational grazed sward. Grass and Forage Science, v.43, n.1, p.15-27, 1988

PEDREIRA, J.V.S.; MATTOS, H.B. Crescimento estacional de vinte e cinco espécies ou variedades de capins. Boletim de Indústria Animal, v.38, p.117-143, 1981.

PEDREIRA, B.C.; PEDREIRA, C.G.S.; DA SILVA, S.C. Acúmulo de forragem durante a rebrotação do capim-xaraés submetido a três estratégias de desfolhação. Revista Brasileira de Zootecnia, v.38, n.4, p.618-625, 2009.

PENNING, P.D.; PARSONS, A.J. Intake and behavior responses by sheep to changes in sward characteristics under continuous stocking. Grass and Forage Science, v.43, n.15, p.15-28, 1991.

PEREIRA, L.E.T.; PAIVA, A.J.; DA SILVA, S.C. et al. Sward structure of marandu palisadegrass subjected to continuous stocking and nitrogen-induced rhythms of growth. Science Agriculture, v.67, n.5, p.531-539, 2010.

SANTOS, P.M.; CORSI, M.; BALSALOBRE, M.A.A. Efeito da frequência de pastejo e da época do ano sobre a produção e a qualidade em Panicum maximum cvs. Tanzânia e Mombaça. Revista Brasileira de Zootecnia, v.28, n.2, p.244-249, 1999.

SANTOS, P.M.; CORSI, M.; PEDREIRA, C.G.S. et al. Tiller cohort development and digestibility in tanzania guinea grass (Panicum maximum cv. Tanzania) under three levels of grazing intensity. Tropical Grasslands, v.40, p.84-93, 2006.

SBRISSIA, A.F., Da SILVA, S.C. O ecossistema de pastagens e a produção animal In: REUNIÃO ANUAL DA SOCIDADE BRASILEIRA DE ZOOTECNIA, 38., 2001, Piracicaba. Anais.. Piracicaba: SBZ, 2001. p.731-754.

SBRISSIA, A.F.; Da SILVA, S.C. Comparação de três métodos para estimativa do índice de área foliar em pastos de capim-marandu sob lotação contínua. Revista Brasileira de Zootecnia, v.37, n.2, p.212-220, 2008.

TRINDADE, J.K.; DA SILVA, S.C.; SOUZA JÚNIOR, S.J. et al. Composição morfológica da forragem consumida por bovinos de corte durante o rebaixamento do capim Marandu submetido a estratégias de pastejo rotativo. Pesquisa Agropecuária Brasileira, v.42, p.883-890, 2007.

VILELA, D.; PAIVA, P.C.A.; LIMA, J.A. et al. Morfogênese e acúmulo de forragem em pastagem de Cynodon dactylon cv. coastcross em diferentes estações de crescimento. Revista Brasileira de Zootecnia, v.34, n.6, p.1891-1896, 2005.

WOLFINGER, R.D. Covariance structure selection in general mixed models. Communications in Statistics Simulation and Computation, v.22, n.4, p.1079-1106, 1993.

ZANINI, G.D.; SCHMITT, D.; SBRISSIA, A.F. Participação de colmo na forragem acumulada em pastos de capim-Aruana submetidos a frequências e severidades de desfolhação por ovinos. In: CONGRESSO DE INICIAÇÃO CIENTÍFICA E PÓSGRADUAÇÃO DO SUL DO BRASIL, 1., 2010, Florianópolis. Resumos... Florianópolis: Universidade do Estado de Santa Catarina, 2010. p.13-15.

ZIMMER, A.H. Efeito dos níveis de nitrogênio e resíduos de pastejo sobre a produção, estrutura e qualidade das cultivares Aruana e Vencedor de Panicum maximum Jacq. 1999. 213f. Tese (Doutorado em Zootecnia) - Universidade Estadual Paulista, Jaboticabal. 